\title{
Is dental caries reaching epidemic proportions in Brazil?
}

We read with interest the recent Perspective article by Taubman and Nash ${ }^{1}$ relating to the development of vaccines against dental caries. These authors affirm that: "In many countries such as Brazil and China, [dental caries] is reaching epidemic proportions, and it is clear that a more effective public-health measure to combat dental caries is needed"; however, the source of this statement was not cited. An epidemic is defined as: "The occurrence in a community or region of cases of an illness, specific health-related behavior, or health-related events clearly in excess of normal expectancy"2. Nowadays in Brazil, the susceptibility of individuals to dental caries is related to biological and socioeconomic inequalities ${ }^{3}$, which is similar to other countries. It is true that dental caries has previously been a public health problem and might continue to be so; however, the statement in the abstract of the article by Taubman and Nash that: "...this disease is reaching epidemic proportions..." is inaccurate. Between 1986 and 2002/2003, the prevalence and incidence of dental caries in Brazil decreased by approximately $58.2 \%$ in 12 -year-old children (TABLE 1). These data are available on the World Health Organization web site ${ }^{4}$.

Additional studies show that in some cities of Brazil the decrease in the prevalence of dental caries is similar to that of developed countries (TABLE 2).

This letter is intended to alert the readers of Nature Reviews Immunology to the fact that the prevalence of dental caries in Brazil is not "reaching epidemic proportions" but is, in fact, decreasing. This is an important distinction as its misinterpretation could have significant potential to damage the reputation of third parties.

\section{Ramiro Mendonca Murata* and Vanessa Pardi ${ }^{\ddagger}$}

* Department of Physiological Sciences, Faculty of Dentistry of Piracicaba, State University of Campinas, Av. Limeira, 901, CEP: 13400-903, Piracicaba, São Paulo, Brazil.

${ }^{\ddagger}$ Graduate Program in Community Health, Faculty of Dentistry, University of Sagrado Coração, R. Irma Arminda, 10-50, CEP: 17011-160, Bauru, São Paulo, Brazil.

Correspondence to R.M.M. e-mail: ramiro@fop.unicamp.br

1. Taubman, M. A. $\&$ Nash, D. A. The scientific and public-health imperative for a vaccine against dental caries. Nature Rev. Immunol. 6, 555-563 (2006).

2. $\quad$ Last, J. M. A Dictionary of Epidemiology (Oxford Univ. Press, 1983).

3. Antunes, J. L., Peres, M. A., de Campos Mello, T. R. \& Waldman, E. A. Multilevel assessment of determinants of dental caries experience in Brazil. Community Dent. Oral Epidemiol. 34,146-152 (2006).

4. World Health Organization. WHO Oral Health Country/Area Profile Programme [online], < http://www.whocollab.od.mah.se/amro/brazil/data/brazilcar.html > (2006).

5. Souza, M. L., Bastos, J. L. \& Peres, M. A. Trends in dental caries rates in 12- and 13-year-old schoolchildren from Florianópolis (Brazil) between 1971 and 2005. Oral Health Prev. Dent. 4, 187-192 (2006).

6. Meneghim, M. de C. et al. Trends in caries experience and fluorosis prevalence in 11- to 12-year-old Brazilian children between 1991 and 2004. Oral Health Prev. Dent. 4, 193-198 (2006).

7. da Silva Bastos, R., Olympio, K. P., Bijella, V. T., Buzalaf, M. A. \& de Magalhães Bastos, J. R. Trends in dental caries prevalence in 12-year-old schoolchildren between 1976 and 2001 in Bauru, Brazil. Public Health 119 , 269-275 (2005). 
8. Traebert, J., de Lacerda, J. T., Fischer, T. K. \& Jinbo, Y. Dental caries and orofacial pain trends in 12-year-old school children between 1997 and 2003. Oral Health Prev. Dent. 3, 243-248 (2005).

9. Pieper, K. \& Schulte, A. G. The decline in dental caries among 12-year-old children in Germany between 1994 and 2000. Community Dent. Health 21 , 199-206 (2004).

10. Nishi, M., Stjernsward, J., Carlsson, P. \& Bratthall, D. Caries experience of some countries and areas expressed by the Significant Caries Index. Community Dent. Oral Epidemiol. 30, 296-301 (2002).

11. Carvalho, J. C., Van Nieuwenhuysen, J. P. \& D'Hoore, W. The decline in dental caries among Belgian children between 1983 and 1998. Community Dent. Oral Epidemiol. 29, 55-61 (2001).

\section{Table 1 | DMFT index of 12-year-old children in Brazil

DMFT Year \\ $6.7 \quad 1986$ \\ 6.7-4.9 1986-1990 \\ $4.9 \quad 1994$ \\ $3.1 \quad 1996$ \\ $2.8 \quad 2002-2003$}

The DMFT index is a general indicator of the prevalence of dental caries in a population. It is obtained by calculating the number of decayed (D), missing (M) and/or filled (F) teeth over the total number of teeth examined $(\mathrm{T})^{4}$.

Table 2 | Decrease in the prevalence of dental caries in Brazil and in several developed countries

\begin{tabular}{|c|c|c|c|c|}
\hline Years & $\begin{array}{l}\text { DMFT index } \\
\text { of } 12 \text {-year- } \\
\text { old children }\end{array}$ & $\begin{array}{l}\text { Percentage } \\
\text { reduction }\end{array}$ & Country (city) & References \\
\hline $\begin{array}{l}1971 \text { and } \\
2005\end{array}$ & 9.2 to 0.8 & $91.3 \%$ & $\begin{array}{l}\text { Brazil } \\
\text { (Florianópolis } \\
\text { ) }\end{array}$ & 5 \\
\hline $\begin{array}{l}1991 \text { and } \\
2004\end{array}$ & 6.7 to 1.2 & $82.1 \%$ & $\begin{array}{l}\text { Brazil } \\
\text { (Iracemápolis) }\end{array}$ & 6 \\
\hline $\begin{array}{l}1976 \text { and } \\
2001\end{array}$ & 9.89 to 1.53 & $84.5 \%$ & $\begin{array}{l}\text { Brazil } \\
\text { (Bauru) }\end{array}$ & 7 \\
\hline $\begin{array}{l}1997 \text { and } \\
2003\end{array}$ & 2.84 to 1.65 & $41.9 \%$ & $\begin{array}{l}\text { Brazil } \\
\text { (Palhoça) }\end{array}$ & 8 \\
\hline $\begin{array}{l}1994 / 1995 \\
\text { and } 2000\end{array}$ & 2.44 to 1.24 & $49.2 \%$ & Germany & 9 \\
\hline $\begin{array}{l}1987 \text { and } \\
1998\end{array}$ & 4.2 to 2.0 & $52.4 \%$ & France & 10 \\
\hline $\begin{array}{l}1985 \text { and } \\
1998\end{array}$ & 3.3 to 1.0 & $69.7 \%$ & Sweden & 10 \\
\hline $\begin{array}{l}1983 \text { and } \\
1998\end{array}$ & 7.5 to 1.6 & $78.7 \%$ & Belgium & 11 \\
\hline
\end{tabular}

